J. Clin. Chem. Clin. Biochem.

Vol. 19,1981 , pp. $447-451$

\title{
Determination of Triiodothyronine in Serum by Enzyme- and Radioimmunoassay A Comparative Study
}

\author{
By $M$. Oellerich and $H$. Haindl
}

Technical Assistance: I. Isberner

Institut für Klinische Chemie und Institut für Nuklearmedizin, Medizinische Hochschule Hannover

(Received September 5/December 16,1980)

Summary: An evaluation of a heterogeneous enzyme immunoassay for determination of triiodothyronine in serum (Enzymun-Test ${ }^{\circledR} T_{3}$, Boehringer Mannheim) is presented. The enzyme immunoassay was compared with the laboratory routine radioimmunoassay. The precision of both assays was satisfactory at triiodothyronine concentrations between 1.0 and $8.0 \mathrm{nmol} / \mathrm{l}$ (coefficients of variation from day to day $\leqslant 10 \%$ ). Average recoveries of triiodothyronine in pool sera ranged with the Enzymun-Test $\mathrm{T}_{3}$ from $96-104 \%$ and with the radioimmunoassay from $88-111 \%$. A comparison of the results obtained by Enzymun-Test ${ }^{\circledR} T_{3}$ and the radioimmunoassay in a series of 103 patients showed a good correlation between both methods. $L$-thyroxine did not cause a relevant cross-reaction in the enzyme immunoassay. About 20 unknown samples can be analyzed in triplicate by Enzymun-Test ${ }^{\circledR} T_{3}$ within 260 minutes.

\section{Bestimmung von Triiodthyronin im Serum mittels Enzym- und Radioimmunotest - Eine vergleichende Studie}

Zusammenfassung: Es wird über die Erprobung eines heterogenen Enzymimmunotests zur Bestimmung von Triiodthyronin im Serum (Enzymun-Test ${ }^{\circledR} \mathrm{T}_{3}$, Boehringer Mannheim) berichtet. Der Enzymimmunotest wird mit einem Radioimmunotest verglichen, welcher gegenwärtig als Routineverfahren eingesetzt ist. Die Präzision beider Tests war bei Triiodthyroninkonzentrationen zwischen 1,0 und $8,0 \mathrm{nmol} / 1$ zufriedenstellend (Variationskoeffizienten von Tag zu Tag $\leqslant 10 \%$ ). Die mittleren Wiederfindungen von Triiodthyronin in Poolseren lagen mit dem Enzymun-Test $T_{3}$ bei 96-104\% und mit dem Radioimmunotest bei 88-111\%. Ein Vergleich der Ergebnisse, welche mit dem EnzymunTest $^{\circledR} T_{3}$ und dem Radioimmunotest bei einer Serie von 103 Patienten erhalten wurde, zeigte eine gute Korrelation beider Methoden. $L$-Thyroxin bewirkte im Enzymimmunotest keine relevante Kreuzreaktion. Etwa 20 unbekannte Proben können als Dreifachbestimmungen mit dem Enzymun-Test ${ }^{\circledR} T_{3}$ in 260 Minuten durchgeführt werden.

\section{Introduction}

During the last few years enzyme immunoassays have gained importance in routine diagnosis (1). So far in the field of in vitro diagnosis of thyroid disorders enzyme immunoassays have been developed for the determination of thyroxine (2-5), thyroxine binding capacity (6), triiodothyronine uptake $(7)$, thyrotropin $(8,9,10)$, triiodothyronine $(2,12)$, thyroglobulin (13) and antithyroglobulin autoantibody (14). In various comparative studies an acceptable correlation between commercially available enzyme immunoassays for the determination of thyroxine and thyroxine binding capacity and corresponding radioimmunoassays has been demonstrated $(15-18)$.

In this study an evaluation of a heterogeneous enzyme immunoassay for the determination of triiodothyronine (2) (Enzymun-Test ${ }^{\circledR} T_{3}$, Boehringer Mannheim) is presented, which has recently become commercially available. As there is no reference method for triiodothyronine the enzyme immunoassay was compared with our radioimmunoassay, which is used as the present routine procedure.

\section{Materials and Methods}

Materials

The reagents for Enzymun-Test ${ }^{\circledR} T_{3}$ were provided for clinical trial by Boehringer Mannheim (D-8132 Tutzing). Kits for the determination of thyroxine binding capacity (Ultragnost ${ }^{\circledR} T_{3}$ ) were purchased from Behring-Werke (D-3550 Marburg). $L$-triiodothyronine and $L$-thyroxine was purchased from Sigma (D-8021 Taufkirchen). $L$-triiodothyronine, p. a. $100 \mu \mathrm{g}$, RIA standard reagent was obtained from Henning (D-1000 Berlin). Lypho-Check ${ }^{\circledR}$ Radioassay Control Serum was purchased from BioRad Laboratories (D-8000 Munich 50). 


\section{Enzyme immunoassay}

Triiodothyronine determinations were performed according to the manufacturer's instructions with an Eppendorf spectrophotometer $1101 \mathrm{M}$ (Eppendorf, D-2000 Hamburg 63) equipped with a flow cell and connected on-line to an electronic data processing system IBM 1130, which printed out the values of the absorbances. The further evaluation of the results was performed either graphically by a manual curve-fit or by the computer using an empiric spline interpolation (Porth, A. \& Oellerich, $M$. in prep.). All determinations were performed in triplicate at a wavelength of $405 \mathrm{~nm}$.

\section{Radioimmunoassay}

Triiodothyronine determinations by radioimmunoassay were carried out with a double antibody technique, which is used as the present routine procedure.

$50 \mu \mathrm{l}$ of serum or $L$-triiodothyronine standard (A), $400 \mu \mathrm{l}$ of barbital buffer containing [ $\left.{ }^{125} \mathrm{I}\right] L$-triiodothyronine (B), $200 \mu$ ] of antiserum against $L$-triiodothyronine $(C)$ and $100 \mu l$ of precipitating antiserum (D) were pipetted by a fully mechanized pipetting system (Automatische RIA-Vorbereitung, Braun-Melsungen, D-3508 Melsungen) and then incubated for 18 hours at room temperature. The long incubation period was chosen primarily for organizational reasons. The samples are then centrifuged for 15 minutes at $2400 \mathrm{~g}$ and the supernatant discarded. The pellet is washed once with $1 \mathrm{ml}$ of bidistilled water. The antibody-bound radioactivity is measured using gamma counters (Packard Instruments, D-6000 Frankfurt/M., Berthold, D-7547 Wildbad). All samples were analyzed in duplicate. Standard curves were calculated by "spline function" (19) using a Diehl Alphatronic calculator (Diehl, D-8500 Nürnberg).

\section{Reagent $A$}

Triiodothyronine-free serum was prepared according to Meinhold \& Wenzel (20). Charcoal ( $200 \mathrm{~g}$, Norit A, Serva, D-6900 Heidelberg) was added to pool serum (1 1), stirred overnight at $4^{\circ} \mathrm{C}$ and then centrifuged for $8 \mathrm{~h}$ at $20000 \mathrm{~g}$. The supernatant was filtered using quartz wool. The values of total protein (biuret-method) and those of electrophoresis determined by use of an Olympus Hite System (11) (Olympus Optical Co., D-2000 Hamburg) pointed to minor differences between the charcoalextracted serum (total protein $67 \mathrm{~g} / \mathrm{l}$; fractions: albumin 0.628 , $\alpha_{1}$-globulin 0.027, $\alpha_{2}$-globulin 0.099, $\beta$-globulin 0.065, $\gamma$-globulin 0.181 ) and the starting material (total protein $70 \mathrm{~g} / 1$; fractions: albumin $0.622 ; \alpha_{1}$-globulin $0.034 ; \alpha_{2}$-globulin 0.101 ; $\beta$-globulin $0.094 ; \gamma$-globulin 0.149). Triiodothyronine-free serum was spiked using lyophilized $L$-triiodothyronine $(100 \mu \mathrm{g}$, RIA standard reagent, Henning, D-1000 Berlin) (0.77$24.6 \mathrm{nmol} / \mathrm{l})$. In some of the recovery experiments $50 \mathrm{mg}$ of $\boldsymbol{L}$-triiodothyronine (Sigma, D-8021 Taufkirchen) was dissolved in $1 \mathrm{ml}$ of $0.2 \mathrm{~mol} / 1 \mathrm{NaOH}$. After dilution with distilled water $\left(1: 10^{6}\right)$ the final solution was used to spike triiodothyroninefree serum.

\section{Reagent $B$}

Barbital buffer (pH 8.4) contained: $80 \mathrm{mmol} / \mathrm{l}$ barbital (5,5'-diethyl-barbituric acid-sodium salt) (Merck, D-6100 Darmstadt), $10 \mathrm{mg} / 1$ rabbit $\gamma$-globulin (Serva, D-6900 Heidelberg), $1 \mathrm{~g} / \mathrm{l}$ human serum albumin (Behring, D-3550 Marburg),

$2.77 \mathrm{mmol} / 1$ ammonium salt of 1-anilino-8-naphthalene-sulphonic acid (Serva, D-6900 Heidelberg), $32 \mathrm{pmol} / 1$ [ $\left.{ }^{125} \mathrm{I}\right] L$-triiodothyronine (specific activity $65000 \mathrm{MBq} / \mu \mathrm{mol}$ ) (Rohstóffeinfuhr, D-4000 Düsseldorf), $0.5 \mathrm{mmol} / 1$ merthiolate (sodium salt of ethylmercurithiosalicylic acid) (Merck, D-6100 Darmstadt).

\section{Reagent $C$}

Triiodothyronine-bovine-serum-albumin-conjugate was prepared according to Oliver (21) and Hesch (22) by coupling $L$-triiodothyronine-methylester-hydrochloride (Henning, D-1000 Berlin) to bovine serum albumin (Behring, D-3550 Marburg) using lethyl-3-(3-dimethylaminopropyl)-carbodiimide hydrochloride (Serva, D-6900 Heidelberg). Two $\mathrm{mg}$ of triiodothyronine-bovineserum-albumin-conjugate dissolved in $1 \mathrm{ml}$ complete Freund's adjuvant (Behring, D-3550 Murburg) and $0.15 \mathrm{~mol} / \mathrm{l}$ sodium chloride solution (volumes $0.5 \mathrm{ml}+0.5 \mathrm{ml}$ ) were subcutaneously injected at various places on the back of rabbits every 14 days. The immunisation was performed for a period of two months. The reaction medium of the assay contains triiodothyronineantiserum in a final dilution of $1: 50000$ (affinity constant $1.02 \cdot 10^{11} \mathrm{l} / \mathrm{mol}$ ).

\section{Reagent D}

As precipitating antiserum anti-rabbit $\boldsymbol{\gamma}$-globulin from donkey (Wellcome, D-3006 Großburgwedel) was used (final dilution in the reaction medium $1: 144$ ).

\section{Reference range}

With the $T_{3}$-radioimmunoassay the reference range used was $1.2-3.7 \mathrm{nmol} / \mathrm{l}$. This reference range was established by the analysis of 150 samples from clinically euthyroid female and male patients (age: $20-65$ years). As the results showed a normal distribution the reference range was calculated from the mean value and two standard deviations.

This reference range was examined for its validity for the patient collective tested in this study. It was found that the median of the results obtained with this collective by radioimmunoassay and Enzymun-Test ${ }^{\circledR} T_{3}$ was in each case in the middle of the above mentioned reference range. Therefore it appeared to be justified to use this reference range with both methods.

\section{Determination of the detection limit}

With the Enzymun-Test ${ }^{\circledR} T_{3}$ the detection limit for triiodothyronine was determined according to Kaiser (24) as the mean value plus the 3 fold standard deviation of a series $(n=20)$ from triiodothyronine-free pooled human serum.

\section{Results and Discussion}

\section{Imprecision}

At diagnostically relevant triiodothyronine concentrations between 1.0 and $8.0 \mathrm{nmol} / \mathrm{l}$ the coefficients of variation of mean values from triplicate determinations ranged from day to day with Enzymun-Test ${ }^{\circledR} \mathrm{T}_{3}$ from $3.6-10.2 \%$ (tab. 1). With the radioimmunoassay coefficients of variation of mean vaiues from duplicate determinations of $3.0-12.7 \%$ were observed at triiodothyronine concentrations between 0.9 and $7.5 \mathrm{nmol} / \mathrm{l}$.

\section{Recovery}

Average recoveries of triiodothyronine added to pooled human serum and to triiodothyronine-free human pool serum are shown in table 2. At triiodothyronine concentrations between 0.77 and $7.68 \mathrm{nmol} / \mathrm{l}$ the recovery ranged with the Enzymun-Test ${ }^{\circledR} \mathrm{T}_{3}$ from $96-104 \%$ and with the radioimmunoassay from $88-111 \%$.

\section{Method comparison study}

Furthermore the triiodothyronine concentration was measured by Enzymun-Test ${ }^{\circledR} \mathrm{T}_{3}$ and radioimmunoassay in 103 specimens from patients. The correlation between the results was good $(r=0.976)$. The slope of the line and the intercept were calculated using the standardized principal component analysis (23). The values of slope and intercept were 1.01 and $0.07 \mathrm{nmol} / 1$. The mean value of the results obtained by EnzymunTest $^{\circledR} \mathrm{T}_{3}(\overline{\mathrm{y}}: 3.53 \pm 1.81 \mathrm{nmol} / \mathrm{l})$ agreed well with that 
Tab. 1. The imprecision from day-to-day of the Enzymun-Test ${ }^{\circledR} \mathrm{T}_{3}$ and radioimmunoassay for determination of triiodothyronine in serum. Assays were performed by radioimmunoassay in duplicate and by Enzymun-Test ${ }^{\circledR} T_{3}$ in triplicate on various days and the mean values were used for calculation of the precision.

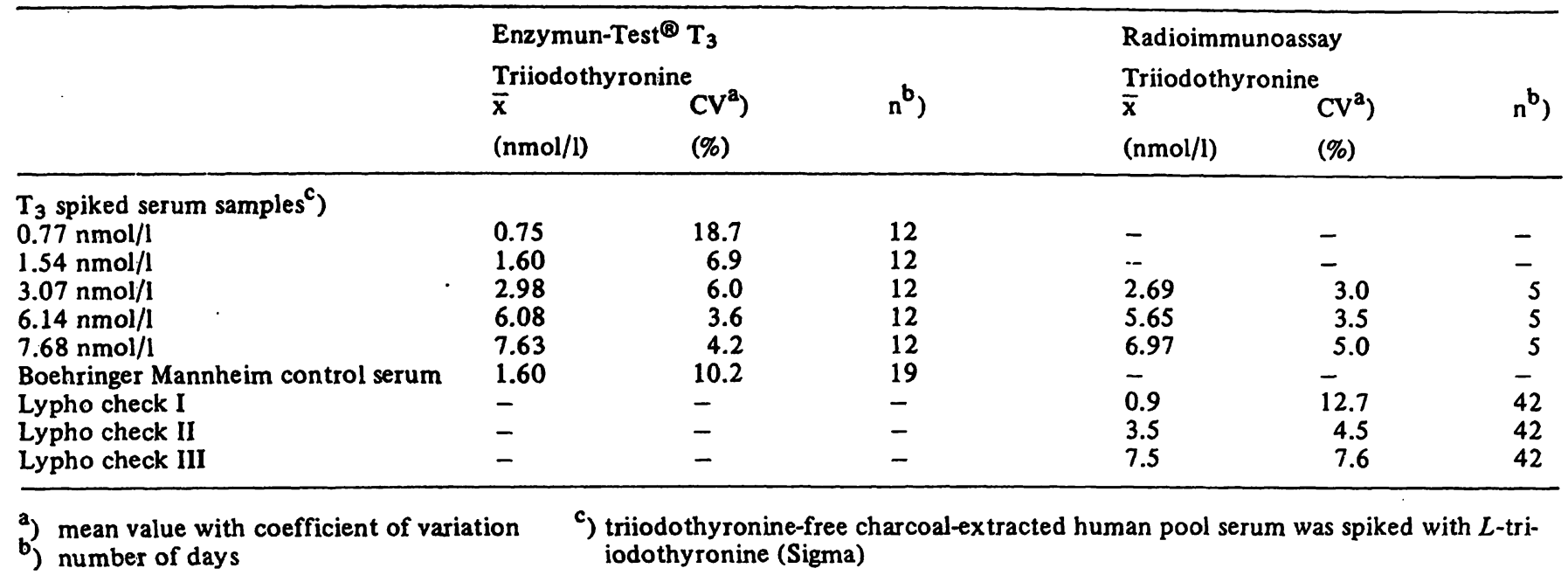

Tab. 2. The recovery of triiodothyronine by Enzymun-Test ${ }^{\circledR} T_{3}$ and radioimmunoassay in spiked serum samples.

\begin{tabular}{|c|c|c|c|c|c|c|}
\hline \multirow{3}{*}{$\begin{array}{l}L \text {-Triiodothyronine } \\
\text { weighed in (nmol/l) }\end{array}$} & \multicolumn{6}{|c|}{ Recovery of triiodothyronine } \\
\hline & \multicolumn{2}{|c|}{$\begin{array}{l}\text { Enzymun-Test }{ }^{\circledR} \mathrm{T}_{3} \\
\left.\overline{\mathrm{x}}^{1}\right)\end{array}$} & \multirow[t]{2}{*}{$\left.n^{2}\right)$} & \multicolumn{2}{|c|}{$\begin{array}{l}\text { Radioimmunoassay } \\
\left.\bar{x}^{1}\right)\end{array}$} & \multirow[t]{2}{*}{$\left.\mathrm{n}^{2}\right)$} \\
\hline & $(\mathrm{nmol} / \mathrm{l})$ & $(\%)$ & & $(\mathrm{nmol} / \mathrm{l})$ & $(\%)$ & \\
\hline \multicolumn{7}{|l|}{$\begin{array}{l}\text { Pooled human serum, } \\
T_{3} \text { Henning }\end{array}$} \\
\hline $\begin{array}{l}- \\
0.77 \\
1.54 \\
3.07 \\
6.14\end{array}$ & $\begin{array}{l}1.89 \\
2.66 \\
3.43 \\
4.92 \\
7.68\end{array}$ & $\begin{array}{r}- \\
100 \\
100 \\
99 \\
96\end{array}$ & $\begin{array}{l}4 \\
4 \\
4 \\
4 \\
4\end{array}$ & $\begin{array}{l}2.07 \\
3.15 \\
3.66 \\
5.30 \\
8.03\end{array}$ & $\begin{array}{r}- \\
111 \\
101 \\
103 \\
98\end{array}$ & $\begin{array}{l}4 \\
4 \\
4 \\
4 \\
4\end{array}$ \\
\hline \multicolumn{7}{|c|}{$\begin{array}{l}T_{3} \text {-free pooled human serum, } \\
\bar{T}_{3} \text { Sigma }\end{array}$} \\
\hline $\begin{array}{l}0.77 \\
1.54 \\
3.07 \\
6.14 \\
7.68\end{array}$ & $\begin{array}{l}0.75 \\
1.60 \\
2.98 \\
6.08 \\
7.63\end{array}$ & $\begin{array}{r}103 \\
104 \\
97 \\
99 \\
99\end{array}$ & $\begin{array}{l}12 \\
12 \\
12 \\
12 \\
12\end{array}$ & $\begin{array}{l}- \\
\overline{2} .69 \\
5.65 \\
6.97\end{array}$ & $\begin{array}{l}- \\
- \\
88 \\
92 \\
91\end{array}$ & $\begin{array}{l}- \\
\overline{5} \\
5 \\
5\end{array}$ \\
\hline
\end{tabular}

of the results determined by radioimmunoassay $(\overline{\mathrm{x}}: 3.57$ $\pm 1.80 \mathrm{nmol} / \mathrm{l}$; $\mathrm{t}$-value $0.958, \mathrm{p}>0.15)$. The correlation between both methods was satisfactory, even when samples from pregnant women with elevated thyroxine binding capacity (114-145\%) were compared (fig. 1).

\section{Specificity}

The cross-reactivity of thyroxine in the enzyme immunoassay was tested using spiked human charcoal-extracted serum (tab. 3). As the reference range of thyroxine is relatively low $(51.5-167.3 \mathrm{nmol} / \mathrm{l})$, a relevant interference of this compound is usually not to be expected.

\section{In terferences}

Haemoglobin concentrations up to $1.0 \mathrm{~g} / 1$ showed no relevant interference in the Enzymun-Test ${ }^{\circledR} \mathrm{T}_{3}$. In severely haemolytic specimens, however, the recovery of triiodothyronine was distinctly reduced (tab. 4).

With severely icteric and lipaemic serum samples the results obtained by Enzymun-Test ${ }^{\circledR} T_{3}$ and radio- 
Tab. 3. Cross-reactivity of thyroxine in the Enżymun-Test ${ }^{\circledR} T_{3}$.

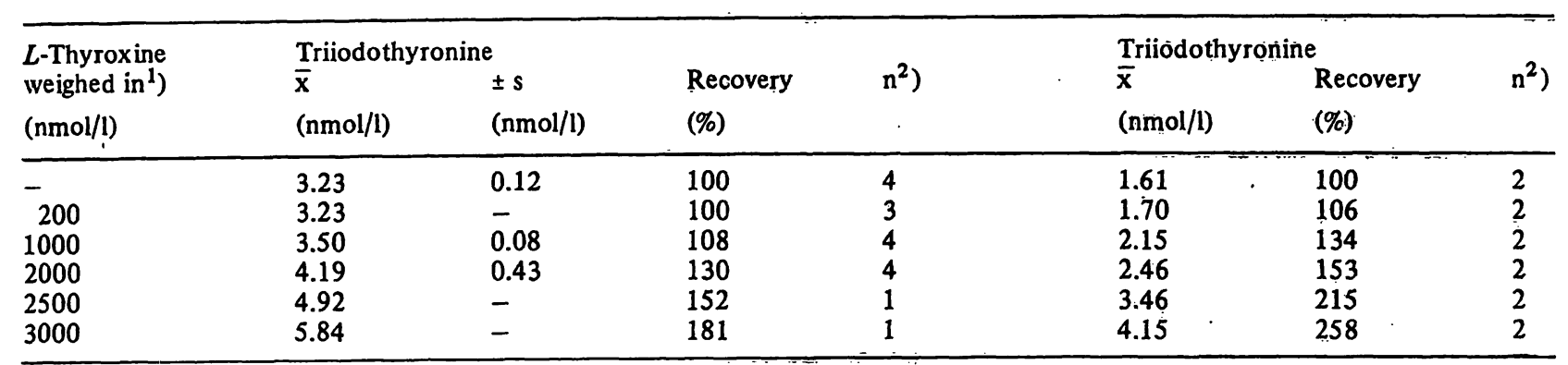

1) $L$-thyroxine was added to charcoalextracted human pool serum containing $3.23 \mathrm{nmol} / \mathrm{l}$ and $1.61 \mathrm{nmol} / \mathrm{l}$ triiodothyronine respectively.

2) number of days

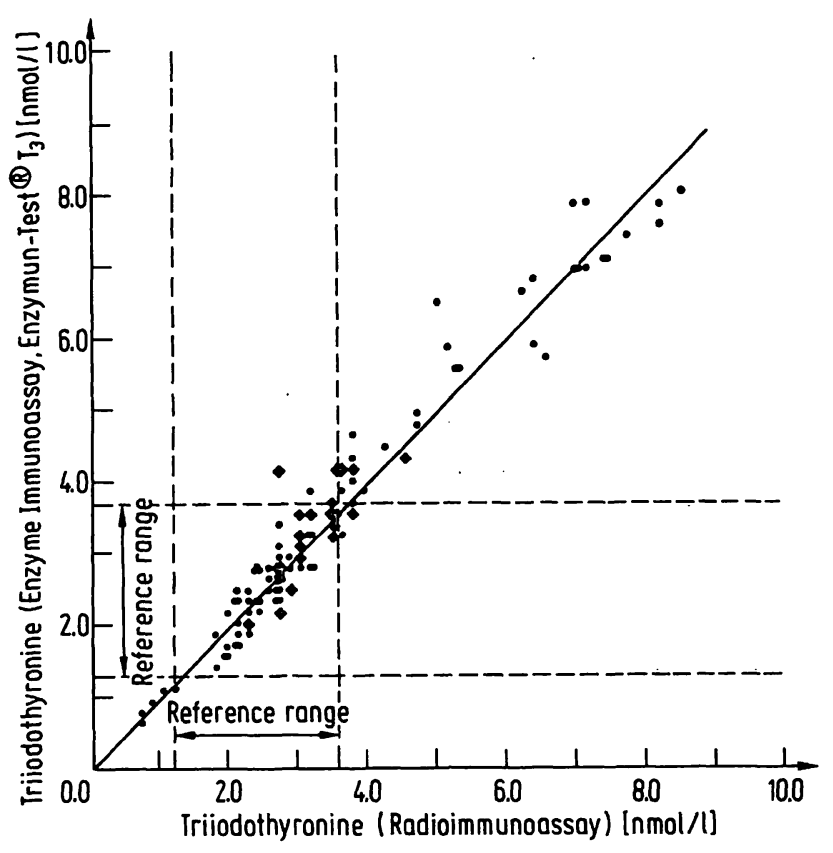

Fig. 1. Serum triiodothyronine concentrations as measured by enzyme immunoassay Enzymun-Test ${ }^{\circledR} \mathrm{T}_{3}$ and radioimmunoassay $(n=103)$. Slope: 1.01 , intercept: $0.07 \mathrm{nmol} / \mathrm{l}$, correlation coefficient: 0.976 . Diamonds represent serum samples from pregnant women with elevated thyroxine binding capacity (114-145\%).
Tab. 4. The influence of haemoglobin on the results of the Enzymun-Test ${ }^{\circledR} T_{3}$.

\begin{tabular}{llll}
\hline Haemoglobin & \multicolumn{3}{l}{ Triodothyronine } \\
& \multicolumn{1}{l}{$\begin{array}{l}\text { x } \\
\text { (g/l) }\end{array}$} & Recovery & $\mathrm{n}^{1}$ ) \\
\hline 0 & $(\mathrm{nmol} / \mathrm{l})$ & $(\%)$ & \\
0.5 & 1.50 & 100 & 4 \\
1.0 & 1.46 & 97 & 2 \\
2.5 & 1.46 & 97 & 2 \\
5.0 & 1.31 & 87 & 2 \\
7.0 & 1.31 & 87 & 2 \\
14.0 & 1.23 & 82 & 1 \\
28.0 & 0.61 & 41 & 1 \\
\hline
\end{tabular}

1) Number of days

immunoassay did not show a significant difference (tab. 5).

\section{Detection limit}

With the Enzymun-Test ${ }^{\circledR} \mathrm{T}_{3}$ a detection limit for triiodothyronine of $0.23 \mathrm{nmol} / \mathrm{l}$ was observed under our experimental conditions. The measuring range of this assay (0.23-9.22 nmol/1) is comparable with that of the radioimmunoassay. The detectability of both asșays appears to be adequate for clinical requirements.

Tab. 5. Comparison of triiodothyronine concentrations determined by Enzymun-Test ${ }^{\circledR} T_{3}$ and radioimmunoassay in icteric and lipaemic serum samples.

\begin{tabular}{|c|c|c|c|c|c|c|}
\hline 。 & $\begin{array}{l}\text { Enzymun } \\
\text { Triiodoth } \\
\overline{\mathrm{x}} \\
(\mathrm{nmol} / \mathrm{l})\end{array}$ & $\begin{array}{l}\dot{T}_{3} \\
e \\
(\mathrm{~s} \\
(\mathrm{nmol} / \mathrm{l})\end{array}$ & $\left.n^{1}\right)$ & $\begin{array}{l}\text { Radioimm } \\
\text { Triiodoth } \\
\overline{\mathrm{x}} \\
\text { (nmol/l) }\end{array}$ & $\begin{array}{l}\text { say } \\
\pm \\
\pm \mathrm{s} \\
\text { (nmol/l) }\end{array}$ & $\left.n^{1}\right)$ \\
\hline $\begin{array}{l}\text { Bilirubin }(\mu \mathrm{mol} / \mathrm{l}) \\
\overline{\mathrm{x}}: 314 \quad \text { range: } 24-823\end{array}$ & 2.1 & $1.2^{2}$ ) & 14 & 2.0 & $1: 1$ & 14 \\
\hline $\begin{array}{l}\text { Triglycerides }(\mathrm{mmol} / \mathrm{l}) \\
\overline{\mathrm{x}}: 18.2 \text { range: } 2.5-71.4\end{array}$ & 3.0 & $\left.2.0^{2}\right)$ & 12 & 3.1 & 2.2 & 12 \\
\hline
\end{tabular}




\section{Practicability}

The Enzymun-Test ${ }^{\circledR} T_{3}$ is easy to perform. 20 unknown triplicate samples can be analyzed by this assay within about 260 minutes. For evaluation of the results an empiric spline interpolation proved to be suitable (Porth, A. \& Oellerich, M. in prep.). Using this curvefitting method the recovery of triiodothyronine $(0.77-7.68 \mathrm{nmol} / 1, \mathrm{n}=6$ ) was on average $102 \%$ (range: 99-107\%) between and $100 \%$ at the calibration points.

\section{Conclusion}

In summary it can be concluded that the enzyme immunoassay, tested for the determination of triiodothyronine

\section{References}

1. Oellerich, M. (1980), J. Clin. Chem. Clin. Biochem. 18, 197-208.

2. Kleinhammer, G., Lenz, H., Linke, R. \& Staehler, F. (1978), in: Enzy mimmunoassay, Grundlagen und praktische Anwendung (Vogt, W. ed.). G. Thieme Verlag, Stuttgart, 4251.

3. a-gent ${ }^{\mathrm{TM}}$ Tetrazyme. Abbott Laboratories, North Chicago, USA (1979).

4. Ullman, E. F., Blakemore, J., Leute, R. K., Eimstad, W. \& Jaklitsch, A. (1975), Clin. Chem. 21, 1011.

5. Jaklitsch, A. P., Schneider, R. S., Johannes, R. J., Lavine, J. E. \& Rosenberg, G. L. (1976), Clin. Chem. 22, 1185.

6. Kleinhammer, G., Deutsch, G., Linke, R. \& Staehler, F. (1978), Clin. Chem. 24, 1033.

7. Greenwood, H. M., Jaklitsch, A. P., Brown, A. G. \& Winfrey, L. J. (1978), $X^{\text {th }}$ international congress of clinical chemistry, Mexico, Abstracts, p. 110.

8. Tanswell, P., Albert, W., Glatz, C., Treffert, C., Linke, R. \& Staehler, F. (1979), in: Praktische Anwendung des Enzymimmunoassays in der Klinischen Chemie und Serologie (Vogt, W. ed.), G. Thieme Verlag, Stuttgart, 91-97.

9. Miyai, K., Ishibàshi, K. \& Kumahara, Y. (1976), Clin. Chim. Acta 67, 263-268.

10. Kato, N., Naruse, H., Lrie, M. \& Tsuji, A. (1979), Anal. Biochem. 96, 419-426.

11. Fink, P. C. (1981), J. Clin. Chem. Clin. Biochem. 19, 379386.

12. O'Sullivan, M. J., Gnemmi, E., Morris, D., Al-Bassam, M. N., Simmons, M., Bridges, J. W. \& Marks, V. (1978), in: Enzyme labelled immunoassay of hormones and drugs ( $\mathrm{Pal}$, S. B. ed.). W. de Gruyter Verlag, Berlin-New York, 301310. in serum, is comparable with the laboratory radioimmunoassay used as the reference method. In accordance with the results presented here the Enzymun-Test ${ }^{\circledR}$ $T_{3}$ showed mainly a good correlation with various other radioimmunological procedures (25). Compared with the radioimmunoassay the Enzymun-Test ${ }^{\circledR} T_{3}$ has the advantage that no radioactive material is used and the reagents have a longer shelf life.
13. Endo, Y., Nakano, J., Ohtaki, S., Izumi, M., Hamaguchi, Y., Yoshitake, S. \& Ishikawa, E. (1979), Clin. Chim. Acta 95, 325-336.

14. Endo, Y., Nakano, J., Horinouchi, K., Ohtaki, S., Izumi, M. \& Ishikawa, E. (1980), Clin. Chim. Acta 103, 67-77.

15. Oellerich, M., Haindl, H. \& Haeckel, R. (1979), J. Clin. Chem. Clin. Biochem. 17, 483-488.

16. Borner, K., Colombo, J. P., Bachmann, G., Haeckel, R., Oellerich, M., Westerink, D., Fischer, M., Wimmer, P., Vogt, W., Tausch, A., Knedel, M., Minder, W., Blum, J. \& Portenhauser, R. (1979), J. Clin. Chem. Clin. Biochem. 17, 471481.

17. Galen, R. S. \& Forman, D. (1977), Clin. Chem. 23, 119121.

18. Finley, P. R. \& Williams, R. J. (1978), Clin. Chem. 24, 165167.

19. Marschner, J., Erhardt, F. \& Scriba, P. C. (1973), in: Radioimmunoassay and related procedures in medicine, International Atomic Energy Agency, Vienna, 111-122.

20. Meinhold, H. \& Wenzel, K. W. (1974), Z. Klin. Chem. Klin. Biochem. 12, 477-486.

21. Oliver, G. G., Parker, B. M., Brasfield, D. L. \& Parker, C. W. (1968), J. Clin. Invest. 47, 1035-1042.

22. Hesch, R. D. \& Hüfner, M. (1972), Acta Biol. Med. Germ. $28,861-864$.

23. Haeckel, R. \& Schneider, B. (1980), GIT Labor-Medizin 3, 99-104.

24. Kaiser, H. (1965), Z. Analyt. Gem. 209, 1-18.

25. Braun, S., Vogt, W., Borner, K., Delcourt, R., Eber, O., Ederveen, A. B., Haas, H., Kagedal, B., Kaltwasser, F., Löünd, H., Oellerich, M., Haindl, H. \& Wagner, H. (1981), J. Clin. Chem. Clin. Biochem., in press.
Priv.-Doz. Dr. M. Oellerich Institut für Klinische Chemie Karl-Wiechert-Allee 9 D-3000 Hannover 61 
